\title{
CZY ŁACIŃSCY OJCOWIE KOŚCIOŁA ZNALI TRAGEDIOPISARZY GRECKICH?
}

Kto nawet pobieżnie przegląda literature patrystyczną łatwo zauważy niechęć, czy tez wręcz wrogie nastawienie ojców Kościoła do teatru. W swoich mowach 1 homiliach ${ }^{1}$, a takze specjalnych traktatach $^{2}$, zwalczali teatr 1 wszystko to, co było z nim zwiazzane, Jako dzieło szatana $i$ oddawanie czci pogańskim bożkom, a szczególnie Bachusowi 1 Wenerze ${ }^{3}$. Nawracający się na chrześcijaństwo juz od II w. składali przy chrzcie, istnfejaca zreszta do dziś,

1 Por. Joarnes Chrysostomus, Homilia contra ludos et theatra, PG 56, 263-270, tłum. W. Kania, Homilie 1 kazania wybrane, PSP 8, Warszawa 1971, 175-181; C. Moss, Jacob of Serugh's homelies on the spectacles of the theatre, "Le ifuseon. Revue d'études orientales" 48/1935/87-112.

2 Por.Tertullianus, De spectacul1s, CCL 1, 227-253, tłum. W. Ayszor, 0 widowiskach, PSP 5, Warszawa 1970, 79-113; Novatianus, De spectaculis, CCL 4, 168-179/PsCyprianus/.

3 Por. Tertullianus, De spectaculis 10, CCL 1, 236-237, PSP 5, 93 -94: "Teatr z racji nieczystości miejsca to nic innego jak świątynia Wenery. Tylko w ten sposób, przez świątynię, widowiska tego rodzaju zostały uznane przez pogan /.../ z Wenerą zaś doskonale zgadza się Liber. Te dwa demony rozkoszy i pijaństwa saz ze sobą w ścisłej zmowie i zaprzysiężentu. Opleka Wenery 1 Libera nad sztukami scenicznymi jest oczywista. To, co właściwe 1 charakterystyczne jest dla sceny, a więc dwuznaczność gestów i ruchów cielesnych, składajz aktorzy jako dar opiarny Wenerze 1 Liberowi, jej ze względu na płeć, Jemu z powodu pijaństwa. Wszystko zaś co wyrażaja głosem, melodia, instrumentami lub recytowanym tekstem wzięły w posiadanie rózne Apolliny, Muzy, Minerwy 1 Merkuriony $/ \ldots . /$. Widzimy więc, że sztuki właściwie pośrięcone są czci tych demonów, którzy kryją się pod imionami $1 \mathrm{ch}$ autorów, a więc nie sa pozbawione bałwochwalstwa, skoro 1ch twórcy uchodzzz za bogów. Co więcej, porinniśmy tść dalej 1 postawić ścisłą preskrypcję, ze demony stały się w ogóle twórczym natchnienien tego rodzaju sztuk 1 starają się wyzyskać dla slebie nieczystosć widowisk, czy innych odmian bałwochwalstwa, aby odwrócić człowieka od Boga 1 zmusić go do składania hołdu $1 \mathrm{~m}$ sanym". 
przys1ęge wyrzeczenia się szatana i jego pychy /renuntio diabolo et pompae et angelis elus $/^{4}$; przez pychę szataniska rozumiano m.in. widow1ska w teatrze, cyrku 1 amfiteatrze ${ }^{5}$. To niezbyt zrozumiałe dla dzisiejszego przeciętnego czytelnika negatywne nastawiente do teatru, uważanego bądź co bądź za jedno z największych kulturalnych osıągnięć św1ata starożytnego, było już przedmiotem dió $w^{6}$, które niestety nie zawsze rozgraniczały teatr 1 dramat od

4 Por. Cyrillus Hierosolymitanus, Catechesis XIX /mystagogica I/, 4-6, SCh 126, 88-92, PSP 9, 302: "Słyszałeś, jak c1 kazano wyciągnąć rękę 1 jakby do obecnego powiedzieć: "Odrzekam się ciebie, szatanie /.../ i wszystkich spraw twoich /.../ i wszelkiej pychy twojej. Pychą szatana saz szaleństwa teatralne, wyścigi konne, polowanie 1 tym podobne marności"; Joannes Chrysostomus, Catechesis ad illuminandos II 20 , SCh 50 bis, 145, Kania/Sakramenty wiary/ 158: "Następnie każe wam kapłan mówić: "Odrzekam ci się, szatanie, odrzekam się twej pychy, twej chwały, twych spraw"; Constitutiones Apostolorum VII 41, 1-2, X. Funk/Didascalia et Constitutiones Apostolorum, Paderbornae 1905/ 445: "Cum ergo renuntiat, qui baptizatur, ita recitet: "lenuntio satanae et operibus elus et pompis eius et cultibus elus et angelis eius et inventis eius ac omnibus quae sub eo sunt"; Tertullianus, De corona $3,2, \mathrm{CCL} 2,1042$; Origenes, In Numeros hom。XII 4, $P G 12,665 \mathrm{CD}$.

5 Caesarius Arelatensis, Sermo 12, 4, CCL 103, 61: "Każdy już mprawdzle wie, co stanowi pychę szatana, ale trzeba wam 1 o niej kilka słór powiedzieć: wszystkie ordynarne widowiska krwawe lub bezwstydne są pychz szatana"; Joannes Chrysostomus, De inani gloria et puerorum educatione $3, \operatorname{SCh} 188,74$, PSP 13, 158-159; tenże, In Julianum martyrem 4, PG 50,673-674; Por. Heiko Jurgens, Pompa diabol1: Die lateinischen Kirchenvater und das antike Theater, Stuttgart 1972; H. Rahner, "Pompa diaboli". Eln Beitrag zur Bedeutungsgeschichte des Wortes "pompe-pompa" in der urchristlichen Taufliturgie, "Zeitschrift fur katholische Theologie" 55/1931/ 239-273; J. H. Waszink, Pompa diaboli, "Vigiliae Christianae" 1/1947/13-41; H. Wey, Die Funktion der b\&sen Geister bei den griechischen Apologeten des zweiten Jahrhunderts nach Christus, Winterhur 1957 .

6 Por. C. Andresen, Theater, A 4: Stellung des Christentums zum Theater, in: Lexikon der Alten Welt, Zurich-Stuttgart 1965, 3029 -3030 ; H. Alt, Theater und Kirche in ihrew gegenseitigen Verhaltnis, Leiden $1970 /$ repr. Berlin 1846/i J. B. Ertau, Pourquoi les P'eres de l'Eglise ont condamné le théatre de leur temps, ParisAngers 1914; Helko Jurgens, Pompa diabol1. Die lateinischen K1rchenvlter und das antike Theater, Stuttgart 1972 ; Ch. Schnusenberg, Das Verhaltnis von Kirche und Theater. Dargestellt an ausgew auf Amalarius von Aietz /775-852/, Bern - Frankfurt a.M. 1981; G. J. Theocharidis, Beitruge zur' Geschichte des byzantinischen Profantheaters im IV und V Jahrhundert, hauptsachlich auf Grund 
przedstawień teatralnych. Teatr dramatyczny wystawiaj tey klasyczne tragedie $i$ komedie by $ł$ okresie patrystycznym w stanie całkowitego upadku. W miejsce wzniosłych tragedil okresu klasycznego, mzbudzających w wiłzach najszlachetniejsze uczucia, pojawiły się na scenie przedstawienia mimu 1 pantomimy, co do których treści 1 Pormy mieli wiele zastrzeżé nawet sami pogani $\theta^{7}$.

Warto się zastanowić, czy autorzy wczesnochrześcijańscy tylko zwalczali teatr 1 nie ulegall zadnym wpływom długowiecznej tradycjl teatralnej? Klasyczne tragedie 1 komedie były przeciez przedmiotem studiów szkolnych. Czy więc 1 od 1 ch znajomości odzegnywal1 się chrześcijanie? Poniewaź jest to zagadnienie stosunkowo rzadko poruszane, chciałabym m miarę mozliwoścl odpowiedzieć na pytanie: czy 1 w jakim stopniu autorzy wczesnochrześcijańscy znall. klasycznq tragedię 1 komedie oraz ich twórców? Odpowiedź byłaby

der Predigten des Johannes Chrysostomus Patriarchen von Konstantinopel, Munchen 1940; W. Weismann, Kirche und Schauspiele. Die Schauspiele im Urteil der latelnischen Kirchenvater, unter besonderer Berdcksichtigung von Augustin, Wurzburg 1972; P. Wolf, Die Stellung der Christen zu den Schauspielen nach Tertullians Schrift "De spectaculis", Leipzig 1897; J. Srutwa, W1dowiska opoki klasycznej w ocenié Kościola afrykańskiego II-V wieku, RTK $27 / 1980 / z$ 4, 43-56; S. Longosz, W1dowiska teatralne zagrozenten dla zycia rodzinnego wg św. Jana Chryzostoma, cijanie a zycie publiczne w cesarstwie rzymskim III 1 IV /praca zbior. red. J. Srutwa, w druku TN KUL/.

7 Por. Vergilius, Aeneis V 64-66: "Mimi solis inhonestis et adulteris placent/ per 1llos enim discitur, quemadmodum/1111cita liant aut facta noscantur"; Macrobius, Saturnaliorum conviviorum II 1, 8, 9: "Pabulonis impudica et praetextata verba iacentis ad pudorem et modest1am versus imitata"; Quint1lianus, Institutio oratoria VI 3,8 ; Ovidius, Tristiae II, 493-518; Julianus Imperator /Apostata/, Epistola 89 b, 304 b-d, tłum. W. Klinger, /Julian Apostata, Liaty, Wrocław 1962/56; C. Gollmann, Zur Beur teilung der offentichen Spiele Roms bei Tacitus, Plinius dem Jungeren, Martial und Juvtnal, Menster 1942; H. Reich, Der Mimus, Bd. 1, Berlin 1903,50-80; I. Friedlander, Darstellungen aus der Sittengeschichte Roms in Zeit von August bis zum Ausgang der Antonine, Bd.2, Leipzig 1910, 112-147. 
zapewne zbyt obszerna 1 mogłaby stanowić nawet przedmiot więszej rozprawy. Ograniczę sie więc tylko do problemu sformułowanego w tytule artykułu. Przez znajomość tę będę rozumiała wyl1czanie 1mienne tragików lub tytułów lch dramatów, cytaty, róznego rodzaju aluzje czy reminiscencje, nawet anonimowe, do $1 \mathrm{ch}$ twórczośc1. Duza pomoo będa stanowiły tu indeksy wydań krytycznych lub przekładón patrystycznych. Juz z góry moźna zakładać, ze dramaturdzy greccy będa leplef znani 1 częściej cytowani przez autorów wczesnochrześcijarskich na Wschodzie niz na Zachodzie, gdzie znajomośc greki w okresie patrystycznym szybko zanikała ${ }^{8}$. Postawione zagadnienie omówie v sposób chronologiczny.

\section{Tragicy archatczni}

Do głównych przedstawicieli starożtnej tragedii greckiej należą, Jak wiadomo, Ajschylos /525-456/, Sofokles /496-406/ 1 Eurypides /480-406/. Ich utmory stanowity podstawcoy kanon lektur szkolnych, skad czerpały wiedze 1 mądrość liczne pokolenta. Do tych więc twórców ograniczę przede wszystkim swe badania.

Tragedie grecka stworzyli jednak w VI w. prz. Chr. tacy poeci, jak: współczesny Solonowi Tespis, Chojrilos 1 Frynich z Aten. Z 1ch twórczośc1 w okresie patrystycznym zachowały sie zaledwie nieliczne Pragmenty, z którymi zapoznawano potomnych przewaźnie w szkole. Ta droga, być moze, poznawali je równiez ojcowie Kościoła. Pierwszego z nich, słowami Horacego, wspomina w jednej ze swych pieśni bp Sydoniusz Apolinary /431-478/ w znanym satyrycznym fragmencie o greckich dramaturgach ${ }^{9}$, dwóch zaś pozostałych św. Hieronim/347-419/ w swej

8 Por. P. Courcelle, Les lettres grecques en 0ccident, Paris $1948^{2}$.

9 Sidonius, Carmen IX 232-238, MGH Auctores antiquissimi 8, 224, lub: ed. Loeb /Cambridge 1936/, 188:

"/.../ unus colit hispidum Platona /.../ orchestram quatit alter Euripidis pictum faecibus Aeschylon secutus aut plaustris solitum sonare Thespin, qui post pulpita trita suo cothurno ducebat olidae marem capellae".

Por. Horatius, De arte poet1ca 275-277:

"Ignotum tragicae genus invenisse Camenae dicitur et plaustris vexisse poemata Thespis, quae canerent agerentque peruncti faecibus ora". 
"Kronice", podkreślając tylko tch sławę bez zaznaczania zasług wobec traged11 ${ }^{10}$. Rzecz clekawa, ze o Tespisie, uwaźanym za ojca tragedi1, nie wspomina nigdzie dociekliwy Hieronim, który w poczet tragediopisarzy greckich zaliczył, nie wiemy z jakich powodów, zyjacego na przełomie VI 1 V w. fllozofa przyrody Ksenofanesa z Kolofonu ${ }^{11}$.

\section{Ajschylos}

Pierwszy 1 najstarszy z trzech wielkich greckich tragediopisarzy Afschylos, autor 70 tragedii 120 dramatów satyrowych, jest w całej zacińskiej literaturze patrystycznej wspominany tylko trzykrotnie: dwa razy w "Kr, nice" przez św. Hieronima pod datami 496 1477 z wyránym zaznaczeniem, ze jest tragediopisarzem ${ }^{12}$, oraz przez wymienionego go ${ }^{13}$, co zdaje się sugerować, iż zna jego imię przede wszystkim za pośrednictwem tego ostatniego. Ta nikła znajomość dramaturga przez racínskich Ojców Kościoła jest tym dziwniejsza, że na Wschodzle by $ł$ on uznany za klasyka i stosunkowo często cytowany, m.in. przez Teofila z Antiochii, Klemensa Aleksandryjskiego 1 Euzebiusza z Cezarei ${ }^{14}$. Jego dramaty, jak to podkreślają E. Rapisarda, a za nim H. Jurgens, wywarły duży wpływ na twórczość żyjącego na przełomie V 1 VI w. chrześcijańskiego poety Drakoncjusza, szczególnie

10 Chronica a. 483, GCS 47, 109, w. 1-2: "Choerilus et Frynichus inlustres habentur".

11 Chronica a. 540, GCS 47, 103 b w. 23-26: "Simonides 1yricus et Phocylides clari habentur et Xenophanes physicus scriptor tragoediarum".

12 Chronicon a. 496, GCS 47, 107 w. 21-22: "Aeschylus tragoediarum scriptor agnoscitur; tamie, a. 477, GCS 47, 109 w. 13-14:

"Aeschylus tragoediarum scriptor agnoscitur".

13 Sidonius, Carmen IX 235, por. notę 9.

14 Por. I. Opelt, Alschylos, JbAC 5/1962/ 192-194. 
napisaną w epickich heksametrach świecką "Tragedię Orestesa"15. Poeta ten jednak nie wymienia nigdzie imiennie Ajschylosa, jakkolwiek wie, ze waztki fabularne jego dramatu były podejmowane juz mczé́niej przez tragediopisarzy greckich 1 rzymskich ${ }^{16}$. Wcześniejszy znawca twórczości Drakoncjusza, C. Rossberg nie dostrzegał jednak zadnego wpływu greckiego dramaturga na "Tragedię Orestesa", ale jedynie oddziaływanie słownictwa Wergiliusza, Owidiusza, Lukana, Stacjusza 1 Klaudiana ${ }^{17}$. Ajschylosowego wpływu nie zauważy równieź współczesny wydawca świeckich pieśni Drakoncjusza, J.M. D1az De Bustamante ${ }^{18}$.

\section{Sofokles}

Drugi z wielkiej trójki greckich tragediopisarzy - Sofokles, autor ok. 120 tragedil 1 dramatów satyrowych, jest pierwszym dramaturgiem znanym szerszemu kręgowi lacińskich 0jców Kościoła. Pierwszym zaś z nich, który wymienił jego imię by tertulian/155220/. W traktacie "0 duszy", wylicza m.1n. szereg wypadkó znanych z mitologii lub historii, w których jest mora o waźnych niekiedy wydarzeniach zapowladanych bohaterom we śnie. Hóród nich znajduje sie, nie wiadomo skąd zaczerpnięta, anegdota o Sofoklesie, który we ́́nie miał odnaleźć złotą koronę ${ }^{19}$. Innym zaś razen Tertulian

15 Tekst traged11: MGH Auctores antiquissimi 14, 197-286, lub: Draconzio, La tragedia di Oreste, ed. E. lapisarda, Catania 1951. 0 mpływie Ajschylosa por. E. Mapisarda, dz. cyt.. s. VII -VIII, 37-38, 44, 184 oraz 1ndeks pod terminem "Aeschilus"; Heiko Jurgens, Pompa diaboli. Die lateinischen Kirchenvater un das antike Theater, Stuttgart 1972, 7 .

16 Por. Orestis tragoedia 13-14, MGH Auctores antiquissimi 14, 197: "Te rogo, Melpomene, tragicis desoende cothurnis et pede dactylico resonante quiescat lambus".

17 C. Hossberg, De Dracontio et Orestis quae vocatur tragoediae auctore eorundem poetarum Vergilil ovidii Lucani Statii Claudiani Imitatoribus, Nordae 1880 .

18 Por. J. M. Diaz De Bustamante, Draconcio y sus carmina profana. Estudio biografico, introducción y edición critica, Santiago de Compostella 1978.

19 De antma 46, 9, CCL 2, 852: "Coronam auream cum ex arce Athenae perdidissent, Sophocles tragicus somniando redinvenit"; por. A. d'Ales, Tertullien helléniste, "Revue des études grecques" $50 / 1937 / 333$. 
wymienia dwukrotnie anonimowo podobna,uszczypliwa anegdote, dotycząca sofoklesowej tragedil "Król Edyp", której Pabułę 1 jej autora mieli wyśmiać Macedończycy ${ }^{20}$. Historia Edypa nie była mu obca, skoro jeszcze kilka razy czynił do niej aluzje ${ }^{21}$. Trudno jednak powiedzieć, czy znal ja z mitologil, czy z lektury tragedii Sopoklesa. Tertulian przytoczył równiez bezimiennie krazżace przysłowie, iz "czas wszystko wyświetla", które, jak sił okazuje, jest sentencja pochodzaca z zaginionego dzieła Sofoklesa22. Podsumowując powyzsze uwagl trzeba powiedziec, ze znajomość Sofoklesa u afrykańskiego Apologety była bardzo powierzchowna 1 wydaje sie, $1 z$ opierała sie ona nie tyle na osobistej lekturze jego dramatón, ile na potocznie zasłyszanych informacjach.

Pewną drobną aluzje do sofoklesowych dziejów Edypa spotykamy takze u drugiego apologety racińskiego Minucjusza Feliksa ${ }^{23}$.

20 Ad nationes I 16,5, CCL 1, 34-35, PSP 29, 65-66: "Skoro tylko wyszedł na scene Edyp z wykłutymi oczami, "racedonczycy] wybuchnęl1 śmiechem 1 szyderstwem. Zmieszany takim potraktowaniem roli aktor powiada: "Panowie, czyz nie spodobałem sie wam?" Macedończycy odpowiedzieli: "Ależ tak. Grasz wspaniale. Tylko albo autor był najgłupszy, skoro tak napisał, albo Edyp był szaleńcem, skoro tak postapił". Następnie jeden do druglego dodal: "Chodzil do matk1"; por. Apologeticus 9, 16, CCL 1, 104, POK 20,46; E. Nbldechen, Tertullian und das Theater, ZKG 15/1895/ 163 i A. d'Ales, Tertullien helléniste, art. cyt., 333 .

21 Por. Ad nationes I 7, 27, CCL 1, 20, PSP 29, 53: "LChrześc1Janiej wcale nie napadaja na tragedie Tyestesa 1 Edypa". - Tragedia Edypa polegała na tym, ze gdy sie dowiedziaz, iz ma za tonę swoja matke, dobrowolnie wykłuł sobie oczy.

22 Apologeticus 7, 13, CCL 1, 100, РOK 20, 37: "Dobrze zaś jest, ze, jak to także wasze przysłowia 1 sentencje poświadczaja, "czas wszystko myświetla", stosownie do wskazań natury, która tak zarządzila, ze nic długo nie zostaje w ukryciu, chociaźby pogłoska tego nie rozniosła" - "Omnia tempus revelat /.../ ut nihil diu lateat". /por. Ad nationes I 7,6 , CCL $1,18 /=$ Sophocles, Frg. $280 . \mathrm{N}^{2}$. Por. A. Otto, Sprichworter und sprichwrterliche iedensarten der Romer, Leipzig 1890, 343, 5.

23 Octavius 31, 3, CSEL 2, 44, РОК 2, 66: "U Pers6\% dozwolone jest mieć stosunek z matka /.../ wasze dzieła historyczne 1 masze dramaty, które chętnie czytacie 1 słuchacie, chełpla się kazirodztwami". 
Wydaje sie jednak, te wzmianka ta 1 tym razem nie wynika z bezpośredniej znajomości dranatów Sofoklesa, lecz z lektury apologetycznych pism Tertuliana.

Równie mglista znajomość twórczości Sofoklesa zauwazamy u św. Ambrozego /339-397/. Chcąc w jednym ze swoich listów wykazać starsze pochodzenie postaci biblijnych od wybitnych nawet sylwetek śwlata pogańskiego, zacytował rzekoma sentencje imiennie wymientonego Sofoklesa, który miał byé o wiele młodszy od Joba 1 Dam1da ${ }^{24}$. Okazuje sie Jednak, te sentencja ta pochodzi nie od Soroklesa, ale od Filona Aleksandryjsk1ego ${ }^{25}$. Biskup Mediolański znaz więc Imle wielkiego dramaturga greckiego, lecz nle mamy zadnych podstaw, aby sądzić, ze osobície czytaz jego dramaty.

W tym samym niemal czasie wspomina Sofoklesa imiennie chrześc1jańsk1 retor afrykańsk1 - Arnoblusz Ateńczyk, tyjący w 1. poz. IV wieku. Zaznacza on, ze nie kto 1nny, ale Solokles utrwaliz tradycje, ze Mars urodzil sie w granicach Tracj1, czyniac przez to bezimienna aluzjo do Antygony mspominajzcej o tym rakcie ${ }^{26}$. Wydaje sie jedhak, ze ten szczegóz mitologiczny, dotyczzoy miejsca narodzin Marsa, zaczerpnał Arnobiusz nie tyle z osobistej znajomóc1 tragedi1 Sofolklesa, 1 le z lektury "Protreptyka"' Klemensa Aleksandryjskiego, który o tym wspomina ${ }^{27}$. W dwóch innych miejscach Arnobiusz, p1sząc o przejmujacym clerpientu Herkulesa, mymienta

24 Epistola $7 / 37 /, 28$, CSEL 82, 57, lub PL 16, 1137: "Qu1s est qui Sophoclea in medium ferat carmina dicentia: "Juppiter mihi praeest, nullus autem hominum". Quanto ant1 qui or Job, quanto vetustior David?. Agnoscant ergo de nostris se habere quaecunque praestantiora locuti sunt"?

25 Por. Sophocles, Frg., $688 \mathrm{~N}^{2}=$ Ph1lo Alexandrinus, Quod omn1s probus liber $3,19$.

26 Adversus nationes IV 25, CSEL 4, 161: "Quis [prodit Martem/ in Thraciae finibus procreatum? Non Sophocles Atticus, cunctis consentientibus theatris?"; por. Sophocles, Antigona 969 nst.

27 Protrepticus II 29, 3, SCh 2, 84: "Ares, kt6rego czcza Jak tylko moga poeci /.../ pochodzil według Eplcharma ze sparty, Sofokles zaś uważał go za Traka". 
nawet tytuł tragedi1 Sofoklesa - "Trachinki", opisujqcej to wydarzenie ${ }^{28}$. I w tym mypadku nie wydaje sie, by afrykarski retor osobí́oie slegal po te tragedię, lub oglądał ja w teatrze, ale jej treść poznał prawdopodobnie, Jak na to wskazuje słownictwo, od cycerona ${ }^{29}$, albo tez z jakiejś granej wówczas pantomimy, opartej na traged11 Sofoklesa 30 .

Najwiecej jednak konkretnych informacji biograficznych o Sofoklesie dostarczył nam św. Hieronim. Nie tylko bowiem podkreśliz jego talent jako tragika, lecz wskazał na początek jego działalności, który miał miejsce po bitwie pod Salaminą 1 wypęzeniu Tem1stoklesa, to znaczy w $471 \mathrm{r}$., oraz wymlen1ł współczesnych mu słamnych rywali Eurypidesa 1 Arystofanesa ${ }^{31}$, takze czas 1 miejsce jego śmierci ${ }^{32}$, a nawet podal zaczerpnięta z lektury Cycerona, anegdote,

28 Adversus nationes IV 35, CSEL 4, 170: "11la proles Jovis Sophoclis in Trachinils Hercules pestiferi tegminis circumretitus indagine miserabiles edere inducitur helulatus, violentia doloris frangi atque in ultimam tabem diffluentium viscerum maceratione consumi"; tamże, VII 33, CSEL 4, 266-267: "Indignat10 relanguescit Alcidae, si tragoedia Sophoclis cui Trachiniae nomen est /.../ actitatur?n

29 Por. Cicero, Tusculanae disputationes II 20: "Herculem /.../ qui $/ \ldots /$ dolore frangebatur $/ \ldots /$ quas hic voces apud Sophoclem In Trachinils edit" oraz zwroty: "viscerum maceratione", "lacerat viscera", "In ultimam tabem", "consumi" = Adversus nationes IV 35 jak wyżej. Zalezność te widzi Elmenhorst/PL 5 , 1073/ oraz W. Kroll /Arnobiusstudien, "Rheinisches Museum" 72/1917-1918/74, Anm. 1, oraz H. Jurgens, Pompa diaboli, dz.cyt., 11.

30 Por. A. J. Festugière, Arnobiana, vc 6/1952/ 242.

31 Chronicon a. 471, GCS 47, 109, พ. 21-26: "Sofocles tragoediarum scriptor primum ingenil sui opera publicavit /.../ Sofocles et Euripides clari habentur"; tamze, a. 438, GCS 47, 114 w. 3-4: "Aristofanes clarus habetur et Sofocles poeta tragicus"; In Dan1elem III 11, 2 b, CCL 75 A, 898: "apud Salaminam navaie certamen, quando Sophocles et Euripides clari habebantur et Themistocles in Persas fugiens, hausto tauri sanguine perilt".

32 Chronicon a. 408, GCS 47, 116 w. 18: "Sofocles Athenis moritur". 
Jak to oskarzony o starcze niedołęstwo bronil przed sąem swej poczytalnośc1 ${ }^{33}$. Te biograficzne wiadomośc1 uzupełnił współczesny mu raciński historyk Orozjusz /390-423/ informacja, ze razem $\mathrm{Pe}-$ ryklesem został wybrany przez Ateńczykóm na stratega ze względu na tragediopisarska sławę ${ }^{34}$. Niektóre z powyższych danych Hieronima powtórzyli niemal dosłownie póńniejsi kronikarze Prosper z Akw1tani1 $/ 390-455 / 35$ i św. Izydor z Sew1111 $/ 560-636 / 36$.

U późniejszych łacińsk 1ch pisarzy wczesnochrześcijańskich wypowiedzi na temat Sofoklesa byky coraz bardziej skape 1 zdawkowe. Wspominany juz wyzej Sydoniusz Apolinary zaznaczył tylko, ze Sofokles $z$ Eurypidesem utorowali droge ateńskiemu teatrowi, umazajac lch za jego wcielenie, oraz wymienit ich obok kynnego komediopisarza - Menandra ${ }^{37}$. Podobnie, zyjacy w 2. poł. VI w., poeta Wenancjusz Portunatus /540-601/ zdawkowo tylko mspomnial "mądrego Sofoklesa", którego imieniem chciałby zaszczycić układane przez siebie

33 Epistola 52, 3, 6, PL 22, 529, tłum. J. Czuj /św. Hieronim, Listy, Warszawa 1953/, I, 332: "Gdy Sofokles z powodu zbyt posunietej starośc1 1 zaniedbania spraw majatkowych oskarzony został przez synów o obłed, odczytal przed sędziami tragedię - Edypie, którą właśnie napisał, 1 tak wielkiej mądrości w podeszłym juz wieku dał dowód, iż surowy trybunał pozyskał dla teatru". Por. C1cero, Cato malor 13; P. Mazon, Sophocle devant ses Juges, "Revue des études anciennes" 47/1945/ 82-96.

34 Historiae I 21, 15, PL 31, 742, CSEL 5, 78: "Athenienses tanta bellorum tempestate permoti duo duces deligunt, Periclae spectatae virtutis virum et Sophoclem scriptorem tragoediarum".

35 Epitome Chronicae 191, PL 51, 543: "Xerxes regnat annis XX, quo tempore Sophocles et Euripides clari habebantur".

36 Chronica 44, PL 83, 1034: "Xerxes regnat annis XX. Aeschylus, Pindarus, Sophocles et Euripides tragoediarum scriptores, celebrantur Insignes"; Ethymologiae V 39, 19, PL 82, 226: "Quinta aetas: /.../ Xerxes, an. XX Sophocles et Euripides tragoedi celebrantur".

37 Carmen XXIII 125-130, ed. Loeb, 290-292:

"H1c 81 syrmate cultus et cothurno

Intrasset semel Atticum theatrum,

Cessistent Sophocies et Euripides;

Aut $s 1$ pulpita personare socco

Comoedus voluisset, huic levato

Palmam tu digito dares, Menander". 
piénín ${ }^{38}$. Inny wreszcie poeta tego samego okresu, Arator, w swoJej poetyckiej parafrazie Dziejów Apostolskich, nawiązal werbalnie, zdaniem Jurgensa, do "Antygony" Sofoklesa ${ }^{39}$, bez wymieniania go imiennie. U żadnego jednak z tych trzech nie mozna wyraźnie stwierdzić, by którý́ z nich czytał, czy ogląal w teatrze tragedie wielkiego dramaturga. Przekazywali o nim ogólnikowe informacje zaczerpnięte od innych autorów. Hzecz ciekawa, że imienia jego nie wymienia nigdzie św. Augustyn, mimo iż na temat teatru starożynego wypowiadal sie wielokrotnie. Zreszta wydaje sie, ze trudno jest udowodnić u łacińskich Ojców Kościoła bezpośrednią znajomość dzieł Sofoklesa40. 0 lle za swego życia rywalizował z Eurypidesem, to po śmierc1, a tym bardziej w okresie patrystycznym, przegrywał zdecydowanie popularności na rzecz Eurypidesa ${ }^{41}$.

\section{Eurypides}

Z trzech wielkich tragików greckich najbardziej znany i cytowany, obok Homera 1 Menandra, przez łacińskich ojców Kościoła był Eurypides ${ }^{42}$. Jego wpływ dostrzega sie nawet w Plémle św. Nowego Te-

38 Carmen VIII 21, 1-4, MGH Auctores antiquissimi 4, 1, 200:

$$
\begin{aligned}
& \text { "Egregio compacta situ, falerata rotatu } \\
& \text { Atque Sophocleo pagina fulta sopho } \\
& \text { Me arentem vestro madefecit opima rigatu } \\
& \text { Fecit et eloquio quod loquor esse tuo". }
\end{aligned}
$$

39 Por. H. Jurgens, Pompa diabol1, dz. cyt., 10; Arator, De Actibus Apostolorum I 423-425, PL 68, 132:

"Auri cessat amor? qui pectora semper adurit, Quo capitur mortale genus, qua pullulat omne De radice malum, cuius violentior ardet Ambitio" = Antigona 295-297.

40 H. Jurgens; Pompa diabol1, dz.cyt., 11.

41 Por. W. Schmid - 0. Stachlin, Geschichte der griechischen Literatur, Bd. I 2, Munchen 1934,504-505/Sophocles Nachleben/; T. Sin ko, L1teratura grecka, t. I 2, Kraków 1932, 137-138/Sofokles u potomnych/.

42 Por. Th. Bergh, Griechische Literatur, Berlin 1887, 565-567; H. Funke, Euripides, JbAC 8-9/1965-1966/254-279; H. Jurgens, Pompa diaboli, dz. cyt., 12. 
stamentu, u św. Lukasza /Dz 26, 14/ 1 św. Pawła /1 Kor 15, 33/, a w okresie patrystycznym u większości wybitniejszych greckich autorów chrześcijańskich, którzy go znali lub cytowali/np. Klemens Rzymsk1, Arystydes z Aten, Justyn, Tacjan, Atenagoras z Aten, TeoP1l z Antioch11, Klemens Aleksandryjski, Orygenes, Euzebiusz z Cezare1, Bazyl1, Grzegorz $z$ Nazjanzu, Grzegorz z Nyssy, Cyryl Aleksandryjski, Teodoret z Cyru, Izydor z Peluzjum, Apolinary z Laodyce1 itd. $/^{43}$. 0 wiele mniej znali go jednak Ojcowie Lacińscy.

Plerwszym łaćńskim autorem wczesnochrześcijańskim, u którego zauważa się reminiscencje eurypidesowe, był Tertulian. Choclaz w całej swej twórczości nie wymienił ani razu 1mienta wielkiego tragediopisarza, ani tez zadnego tytułu jego tragedi1, to jednak zaperne nieśwladomie użł wiersza z jakiegoś jego zaginionego dramatu w charakterze sentencji w traktacie "Do zony" ${ }^{\mathbf{4 4}}$.

W 100 lat później, co najmniej trzykrotnie, już to imiennie cytuje Eurypidesa, już to czyni tylko doń aluzje Laktancjusz /250 $-330 /$, nauczyciel retoryki wikomedil 1 wychowawca synow Konstantyna Wielkiego. Chcąc, np. w swoich wywodach teologiczno-rilozoficznych zilustrowac pogańskim tekstem Chrystusowa sentencje "Kto sie wywyższa, będzie poniżony" Mt 23, 12/, przytacza imiennie euryp1desowy wiersz z nieznanego nam bliżej dramatu, zbliżony słownictwem do zachowanego eragmentu "Ion"45. Innym znów razem, szukając p pismach poetów, filozorów 1 Sybill1 pogańskich dowodów na jedność Boga, przytacza fragment dzieła Farrona - "Antiquitates rerum divinarum", w ḱórym jest mowa o tych ostatnich. Druga z nich jest L1byssa; wspomniana przez Eurypidesa w prologu dramatu "Lamian"6.

43 Por. H. Funke, Euripides, art. cyt., 254-276.

44 Ad uxorem I 8,4, CCL 1, 382: "Bonos corrumpunt mores congressus mal1" = Euripides, Frg. 1024.

45 Divinae institutiones V 15, 11, CSEL 19, 449: "Neque enim falsa est llla sententia, quae apud Euripidem fertur in hunc modum: "Quae hic mala putantur, haec sunt in coelo bona" = Euripides, Frg. 1118.

46 Tamże, I 6, 8, CSEL 19, 21: "Ceterum Sibillas decem numero fuisse easque omnes enumeravit $\angle$ Varrof sub auctoribus qui de singulis scriptaverint. Primam fuisse de Persis /.../ secundam Libyssam, cuius meminerit Euripides in Lamiae prologo" $=506 \mathrm{~F}$. 
Rozwijajac zaś myśl, ze taka jest śmierć, jakie było zycie, przytacza na jej poparcie anonimowa sentencje mylnie przypisana przezeŕ Silenow1, a według współczesnych krytyków należąca do Eurypidesa ${ }^{47}$. Innym wreszcie razem plętnuje ogólnie grane w teatrach sztuki podkreślając, ze demoralizują one słuchaczy. Wiele trésci pod tym względem dostarczał niewatpliwie 1 Eurypides ${ }^{48}$. Pomimo powyzszych imiennych wzmianek 1 pełnionej Punkcji nauczyciela we mschodniej greckiej metropoli1, trudno jest przypuścić, by Laktancjusz czytał 1 znał dzieła Eurypidesa bezpośrednio, znał je prawdopodobnie $z$ drugiej ręki.

Imle Eurypldesa musiało być znane w IV w., skoro pamiętano 1 nawiedzano jego grób podczas podrózy do miejso świętych, Jak - tym wspomina w 333 r. anonimowy Akwitańczyk, podając jego miejsce $w$ "Itinerarium Burdigalense"49. Niektóre myśl1 1 sformułowania wielkiego Tragika zdaja się oddziaływać na twórczość poetycka tego czasu. Tak np. niektórzy badacze doszukuja się wpływu jego "Hekuby" na wiersze o św. Agnieszce; tworzone przez papieza Damazego/366$384 / 50$ i hymny przypisywane św. Ambrożemu ${ }^{51}$. Ten ostatni, który jak

47 Tamże, III 19, 13, CSEL 19, 242: "Hinc nata est inepta 11la sententia, hanc esse mortem quam nos vitam putemus, 1llam vitam quam nos pro morte timeamus: ita primum bonum esse non nasci, secundum, c1tius mori. Quae ut maioris sit auctoritatis Sileno adtribuitur" = Euripides, Pollyid. Prg. 639; por. A. Nauck, Fragmenta, 21.

48 Tamze, V 10,16-18; CSEL 19,432-433; por. Euripides, Ion 436451.

49 It1nerarium Burdigalense 604, 7, CCL 175, 22: "Mutatio Perip1dis milia $X$. Ib1 positus est Euripidis poeta"; CSEL 39, 27: "Mutat10 Euripidis"/przy stacji Arethusa w Macedoni1/.

50 Por. Epigramma 37, ed. A. Ferrua, Epigrammata Damasiana, C1tta del Vaticano 1942, 176:

"/.../ inmensum parvis superasse timorem

Nudaque profusum crinem per membra dedisse,

Ne domini templum facies peritura videret".

Euripides, Hecuba 568-570.

51 De S. Agnete hymnus 65, 25-28, PL 17, 1211:

"Percussam quam pompam tulit,

Nam veste se totam teg1t,

Curam pudoris praestitit,

Ne quis retectam cerneret".

Por. P. Franchi de'Cavalieri, S. Agnes nella tradizione e nella leggenda, ST 221/1962/294, 300; tenze, Intorno ad alcune remi- 
wiemy, znał dobrze Język grecki, bo przy pisaniu "Komentarza do sześciu dni stworzenia" korzystał obficle z "Hexameronu" św. Bazylego, uzasadniając myśl, ze wybór małżonka nie nalezy do dziewczyny, ale do jej ojca, przytoczył nawet imiennie po grecku, z metrycznym przekładem łacińskim eurypidesowe zdanie ${ }^{52}$. Nie wydaje się jednak, by 1 on zaczerpnłł je bezpośrednio z tragedi1 Eurypidesa, ale znalazł je prawdopodobnie w pismach Filona Aleksandryjskiego 53 . Od niego również zaczerpnął Biskup Mediolański jeszcze jedną euryp1desową sentencją, którą w metrycznym przekładzie łacínskim przenísł z ust Polikseny do ust św. Pelag11 męczennicy ${ }^{54}$.

Najwięcej wzmianek o Eurypidesie spotykamy w pismach śr. Hieronima. W swojej "Kronice" Informuje nas, te był on słynnym tragediopisarzem ${ }^{55}$, ze w 408 r. zmarł w Archelaum ${ }^{56}$, a nawet nawiazując

niscenze classiche nelle leggende agiografiche del IV secolo, ST 19/1908/146-149, 65/1935/2691.

52 De Abraham I 9, 91, PL 14, 476: " Unde 1llud Euripideum quod mirantur plerique, unde translatum sit, manifestum est. Ait enim in persona mulieris, quae tamen maritum volebat relinquere et ad alias petebatur nuptias: [awuwlersz grecki7. Hoc est: Sponsalium quidem meorum pater meus curam subibit; hoc enim non est meum" = Eurypides, Andria 987-988.

53 Por. F. H. Dudden, The Life and Times of St. Ambrose, oxford $1935,8$.

54 Epistola 7/37/, 38, PL 16, 1139-1140: "Quid autem sublimius sancta Pelagia, quae vallata persecutoribus priusquan tamen in eorum conspectum veniret, alebat: Volens morior, nemo me continget manu, nemo oculo protervo violabit virginem, mecum feram pudorem, mecum incolumen verecundiam: nullum praed ones lucrum suae capient insolentlae" = Euripides, Hecuba 458; por. Faller, CSEL 82, 62, 385 /aparat źródłowy]; Ph1lo Alexandrinus, Quod omnis probus liber 17, 116; H. Jurgens, Pompa diaboli, dz.cyt., 16 .

55 Chronicon a. 443, GCS 47, 113 w. 22-23: "Euripides tragoediarum scriptor clarus habetur"; por. note 31 .

56 Chronicon a. 408, GCS 47, 116 \%. 17-18: "Euripides apud Archelaum $/ \ldots /$ moritur". 
do jednej z jego tragedil wyjaśnia, ze Atlas nie jest osobz, lecz bardzo wysoka góra 57 . W innych swoich pismach powołuje się imiennie, za pośrednictwem Porfiriusza, na myśli Eurypidesa ${ }^{58}$, charakteryzuje jego tragedie powtarzajac za Plutarchem, iz mają w soble wiele antyfeministycznych obe $1 \mathrm{~g}^{59}$, zapozycza poznane za pośrednictwem Cycerona wypowiedzi eurypidesowych bohaterów 1 umieszcza je w ustach chrześcijańskich świętych ${ }^{60}$, cytuje fragment zaginionej mowy Cycerona, w której zestawiony został Eurypides z Menandrem61, a nawet, opierajzc sie na ówczesnych słownikach, usiłuje przekładaó na lacinę hebrajskie terminy wykorzystując w tym celu pomoc słownictwa "Medei"62. Mimo tak licznych wzmianek, nie mozna 1 tym razem z cała pewnościa udowodnić, ze Hieronim znał Eurypidesa z wasnej lektury jego traged11; znał go prawdopodobnie poprzez

57 Chronicon, GCS 47, 37 b altissimum adfirmat, qui Atlans vocetur" = Euripides, Ion 1 /Nauck/.

58 Adversus Jovinianum II 14, PL 23, 304: "Euripides in Creta Jovis prophetas non solum carnibus, sed de coctis cibis abstinere, rePert" = Euripides, Frg. $472 \dot{\mathrm{N}}^{2}$; por. Porphyrius, De abstinentia IV 19 ; A. Luebeck, H1eronymus quos noverit scriptores et ex quibus hauserit, Leipzig 1872, 17-18; H. Hagendahl, Latin Fathers and the Classics, Goteborg $1958,149$.

59 Adversus Jovinianum I 48, PL 23, 292: "Totae Euripidis tragoediae in mulieres maledicta sunt"= Euripides, Andria 930; Plutarchus, Praecepta contugalia 40.

60 Vita Paul1 11, PL 23, 26, PSP 10, 29 /Pawel do Antoniega/: "Cieb1e Pan przysłaz, abyś pochowal moje ciało 1 ziemie oddał ziemi /terrae terram reddas $/ n=$ Euripides, Frg. 757, $5 \mathrm{~N}^{2}$; por. C1cero, Tusculanae disputationes III 59: "reddenda terrae est terra".

61 Epistola 52, 8, 3, PL 22, 535, Czuj I, 341: "Pewien poeta, człowiek bardzo wykształcony, autor dialogón między poetami 1 Pilozofami, kaze rozprawiać ze soba Eurypldesowi 1 Menandrowi, a na Innym miejscu Sokratesowi 1 Eplkurowi" = Cicero, Pro Quinto Galio, Frg. $2 / \mathrm{S}_{\mathrm{choe}} 1 \mathrm{l}$.

62 In Danielem 6, 4, PL 25, 524, CCL 75 A, 831: "Cumque ab Hebraeo quaererem, quid significaret, respondit vim verbi sonare "delear" /gr./, quam nos "lllecebram" sive "sfalma" /gr./, hoc est errorem" dicere possumus. Porro Euripides in Medeia "amplakias" /gr./ per "p" non per "b" ha artias"/gr./, id est "peccata" appellat" = Euripides, Medea 116; por. Courcelle, Les lettres grecques, dz. cyt., 51-52. 
tragedie Seneki ${ }^{63}$.

Z niektórych powyzszych informacj1 Hieronima korzystali wspominani juz późniejsi kronikarze, jak Prosper z Akwitani1 64 1 Izydor z Sewil1i65. Równieź wymieniany juź Sydoniusz umieszcza go obok Afschylosa, Tespisa, Sofoklesa 1 Menandra jako wybitnego przedstawiciela nattyckiego teatru"66, a Arnobiusz wspomina o jego tragedi1 "Herkules"67.

Wracajac do końca IV w. nalezy odnotować ciekawa inicjatywę ze strony chrześcijan, która świadczy niewąplivie nie tylko - Jakieś ogólnej znajomości, ale równieź świadomości vkładu Eurypidesa do ówczesnej kultury. Gdy w 362 r. cesarz Julian Apostata wyrzucil nauczycieli chrześcijańskich z katedr publicznych ${ }^{68}$, co w konsekwencji było odsuntęciem młodzieży chrześcijańskiej od studiów w ogóle, światlejsi chrześcijanie zaczęl1 tworzyé wrasną literaturę na podstawie Pisma św. 1 historii Kościoła, wzorowana pod względem formy na dawnych tragediach, komediach, dialogach filozoficznych, liryce 1 eposach. Zaczą to czynić wraz ze swym ofcem, jak nas informuja historycy Sokrates i Sozomen ${ }^{69}$, bp Apolinary z Laodycel syryjskiej /310-390/, który przy układaniu komedi1 wzorował sie na Menandrze, a przy tragediach - na Eurypidesie ${ }^{70}$. Nic

63 H. Hagendahl, Latin Fathers and the Classics, dz. cyt., 151-152; H. Funke, Euripides, art. cyt., 274; A. Luebeck, Hieronymos quos noverit scriptores, dz. cyt., 17-18; A. Danysz, Sw. Hieronim 1 św. Augustyn a literatura śwlecka, "Eos" 6/1910/92-112.

64 Por. note 35.

65 Por. note 36.

66 Por. noty 9137.

67 Adversus nationes VII 33, CSEL 5, 267: "Indignatio relanguescit Alcidae, si /.../ Euripidis aut Hercules actitatur?"

68 Edykt z 17 VI 362 r. /Codex Theodosianus XIII, 3, 5; List 61 Juliana/; por. J. M. Szymusiak, Grzegorz Teolog, Poznań 1965, 124 n. 1.

69 Socrates, HE III 16, PG 67, 417-424, tłum. S. Kazikowski /Sokrates Scholastyk, Historia Kościoła, Warszawa 1972/, 259-260; Sozomenos, HE V 18, PG 67, 1269, tłum. S. Kazikowsk1/Herm1asz Sozomen, Historia Kościoła, Warszawa 1980/, 336-337-

70 Sozomenos, HE V 18, PG 67, 1269, Kaz1kowsk1 336: "Pisal takze komedie wzorowane na utworach dramatycznych Menandra, a poza tym naśladował tragedle Eurypidesa oraz twórczość liryczna Pindara 1 - aby krótko powiedzieć - czerpiąc z ksiagg natchnionych Pisma świętego watki podstawowe do tak zwanej wiedzy ogólnej stworzy w niedługim czasie dzieła co do llości 1 znaczenia 
nlestety nie zachowało sie z tej twórozośc1 dramatycznej, by móc ocentc, w jakim stopniu ulegal on Eurypidesow1. Inicjatywa ta jednak długo pozostawała w świadomości chrześcijan, bo jeszcze 200 lat później odnotowuje ja w swej historil Kasjodor $/ 485-580 /{ }^{71}$. Podobnie, Jak Ajschylosa 1 Sofoklesa, tak równiez Buryp1desa nie wspomina nigdzie imiennie z pewnościa nie czytal w oryginale ze wzglęu na wrodzona niechęć do Języka greckiego ${ }^{72}$. Trudno jednak przypuścic, by odbywając studia nie zetkną sie z Eurypidesem, tym bardziej, ze w swych "wyznaniach" wspomina, 1z przed swym nawróceniem był częstym widzem insoenizacji teatralnych 1 bardzo przezywał odgrywane tam tragedie ${ }^{73}$. Później jednak zdecydowanie krytykował tréść owych przedstawleń, być moze 1 eurypidesowy $\mathrm{ch}^{74}$. W jego pismach spotykamy aluzje lub relacje o Ifigeni1 ${ }^{75}$, o pieśniach dotyczacych Medei ${ }^{76}$. a nawet słownictwo 1 mý́li eurypidesowe ${ }^{77}$, odnośnie do których nie wiemy, czy je przejał od Cycerona, czy od Senek1, czy teź kogoŕ innego.

dorómnujæ̨e os1ągnięciom najsławniejszych w tym zakresie mistrzów; a jeśli chodzi o dobór ́rrodków wyrazu 1 sposób wysłowienia, styl 1 układ treśc1 - bardzo do tych arcydzieł podobne"; por. J. H. Waszink, Die griechische Tragodie im Urteil der Romer und der Christen, JbAC 7/1964/ 139-148.

I1 Historia Tripartita VI 37, 4, PL 69, 1056: "/Apollinaris/ fecit autem et allud opus secundum Menandri fabulas, commoediae similitudine comparatas: imitatus enim Euripidis tragoedias et lyram Pindari".

72 Por. Confessiones I 13, 14, PL 32, 671, tłum. Z. Kubiak/Swięty Augustyn, Wyznania, Warszawa 1982/ 18 .

73 Por. Confessiones III 2, 2-3, PL 32, 683-684, Kubiak 34-35.

74 Por. De civitate De1 II 8, PL 41, 53, tłum. W. Kornatowski /Swięty Augustyn, O Państwie Bożym, I-II, Farszawa 1977/I 142.

75 Por. De civitate Dei XVIII 18, 3, PL 41, 575, Kornatowsk1 II 336.

76. Fyznania III 6,11, PL 32,687 , Kubiak 40: WWiersze i poematy, razem $z$ Medea na skrzydlatym wozie, z pewnościa więcej juz są warte niz pięé zywiołóm o róznych barwach".

77 De c1vitate Dei XIII 17, 1, PL 41, 389, Kornatowski II 102: "Lecz ziemie - powiadajá na to - z kt6rej wzięte sq ciała lstot zywych, oddać trzeba ziemi" = Euripides, Frg. 757, $5 \mathrm{~N}^{2}$, por. note 60 . 
Jedynym wreszcie lacińskim pisarzem wczesnochrześcijańskim, który kilkakrotnie cytuje fachowo po greoku tragedie Eurypidesa 1 wspomina jego $1 \mathrm{mi} e$, był Boecjusz /480-524/, wykształcony klasycznie Pllozof 1 mazz stanu w szuzbie Teodoryka Wielkiego. Mozna więc załozyć, ze czytał on dzieła greckiego tragediopisarza. Skarząc sie na zmienność losu, który jak wiemy, raz przynosił mu szozęśc1e 1 karierę, a innym razem więzienie 1 śmieré, cytował dwukrotnie odpowiednie fragmenty z "Andromachy": raz po lacinie imiennie, ze człowiek bezdzietny jest szczę́liwy wieszczęściu ${ }^{78}$, drug1 raz przytaczajac po grecku dwa wiersze tragediopisarza o złudnośc1 sławy ${ }^{79}$. Innym znów razem spotykamy zacytowany bezimienríe po łac1nie wiersz z "Troad" 80 . W tym samym traktacie "0 pociechach 1 lozofi1" badacze tekstu krytycznego dopatruja sie jeszcze dwóch reminiscencji do eragmentów eurypidesowych ${ }^{81}$.

Podsumowujzc przegląd autorów wspominających lub cytujących Eurypidesa, trzeba powiedzieć, ze znall go przewaźnie z drugiej ręk1. Nawet tak1 erudyta jak św. Hieronim czerpał teksty 1 wiadomośc1 o nim z lektury pism innych autorów. Wydaje się, ze jedynie Boecjusz znał Eurypldesa z własnej lektury, nazywajac go "moim Eurypidesem ${ }^{82}$, co mskazuje na bliska zazyłość z jego pismami. Ze wszystkıch zaśtragedil Eurypidesa najczęściej była cytowana "Andromacha" 1 "Hekuba".

78 De consolatione philosophiae III $7,14-15$, CCL 94, 47, POK 5, 73-74: "I tutaj podtrzymuje zdanie ucznia mego Eurypidesa, który powiedział, ze człowiek bezdzietny wieszczęściu jest szczęśl1wy" = Eurypides, Andromacha 420.

79 De consolatione philosophiae III 6, 3-4, CCL 94, 45, POK 5, 71-72: "Jeśli znów chodzi o sławę, jakże często jest ona złudną. Stąd nie bez słusznoścl tragediopisarz wykrzykuje: "0 sławo, sławo, tysiacom ludzi wielkie zycie wszelkiej pozbawiłas zasług 1 " = Eurypides, Andromacha 319-320.

80 De consolatione philosophiae III m. IX 28, CCL 94, 52, POK 5, 82: "Tý́ wódz śród walki, Tyó wraz początek 1 koniec".

81 De consolatione philosophiae II m. I 9, CCL 94, $19=$ Euripides, Frg. 421 oraz II 7,67, CCL 94, $34=$ Euripides, Frg. 977 .

82 Por. note 78; H. Jurgens, Pompa diaboli 1518. 


\section{Mniej znant tragicy}

Oprócz wyzej wymientonych tragediopisarzy, filarów klasyoznej tragedil greakiej, " pismach wozesnochrześcijańskich autorów spotykamy jeszcze kilku mniej znanych twórców, uwazanych za tragików. Dostarczone przez ojcóm szczegóły o nich sa niekiedy jedynymi, które charakteryzuja lch sylwetki 1 działalnó́ć, poniewaz z 1ch twórczośc1 niewiele albo n1e sie nie zachowało. Tak np. Tertulian, wymieniwszy Sofoklesa, wspomina "tragika Neptolema", napominanego we énie przy grobie Ajaksa ${ }^{83}$. Wydaje sie, ze chodzi tu o Neptolema mitycznego, syna Achillesa, który przywieziony po smierci ojca pod Troje, poniewaz według przepowiedni ten sławny gród nie mógł być bez niego zdobyty, zabił Priama,Poliksenę 1 Astyanaksa. Być moze $z$ powodu tych krwawych wydarzeń Tertulian nazwat go "tragoedus".

Innego hellenistycznego krytyka 1 gramatyka aleksandryjskiego, szóstego z kolel dyrektora Bibllotek1 Aleksandryjskiej, Arystarcha $z$ Samotrake /217-145/, autora prac gramatycznych, komentatora tragedil Ajschylosa 1 Sofoklesa oraz tekstów Arystofanesa 1 Herodota, wymienia w swej "Kronice" św. Hieronim, nazywajac go "Ar1starchus tragoediografus" 84 , oraz 1dący za nim Prosper z Akwi$\operatorname{tan11} 1^{85}$.

Dalszym wspominanym autorem jest fllozof ze szkoły cynickiej, Diogenes z Synopy /413-323/. Tylko od Tertuliana, wymleniajacego dwukrotnie jego "Herkulesan"86 1 od Diogenesa Laertiosa /II w. 87

83 De anima 46, 9, CCL 2, 852: "Neptolemus tragoedus apud thoeteum Troiae sepulcrum Aiacis monitus in somnis ab 1 pso ruina liberat, et cum lapidum senia deponit, dives inde auro redit".

84 Chronicon a. 454, GCS 47, 112, w.2-3: "Aristarchus tragoediografus agnoscitur".

85 Epitome chronicae 198, PL 51, 543: "Tunc etiam Poricides historicus, Cratinus comicus, Aristarchus tragicus exstiterunt".

86 Ad nationes I 10, 43, CCL 1, 28, PSP 29, 60: "Diogenes równiez ó́m1eszył coś u Herkulesa"; Apologeticum 14, 9, CCL 1, 113, POK 20, 68: "Takze Diogenes wyśm1 ewa, nie w1em co, u Herkulesa"; por. Natorp Euripides, KE V 769 w. 41 nst.; Ch. Mohrmann, Tertulilanus, Apologeticum en andere geschriften uit Tertulifanus, Brtase 1 1951, 47.

87 V1tae VI 80. 
dowladujemy sig, te pisał on tragedie.

W pismach autorów wczesnochrześcijańskich istnieje ponadto szereg aluzji, z których moźna wnioskować, iz cytuja anonimowo we własnym przekładzie wiersze jakiegó́ tragediopisarza. Ze zjawiskiem tym spotykamy się, np. u Tertuliana ${ }^{88}$ św. Ambrozego 89.

Z powyższych uwag wynika, ze znajomość tragików greckich u łacı́skich 0jców Kościoła była bardzo powierzchowna. Znali oni w większym lub mniejszym stopniu ich nazwiska 1 tytury $1 \mathrm{ch}$ traged11, a niektórzy cytoweli nawet 1ch utwory, ale znajomość tę czerpalı przeważnte z drugiej ręk1 1 długoriecznej tradycji kulturowej. Na tę znajomośc wpływały równiez niewątpliwie studia odbywane w młodośc1. Spośród wszystkich tragików greckich najczęściej by wspominany 1 cytowany na Zachodzie Eurypides. Wiadomo równiez, ze pod koniec IV w. studiująca młodzieź śplewała nawet przy róznych okazjach eragmenty tragedil greckich, ale nie rozumiała juz $1 \mathrm{ch}$ języka90. Nawet tak1 erudyta, jak św. Hieronim, który spośród autorów wczesnochrześcijańskich najczęściej je wspomina lub cytuje, mimo dobrej znajomości greki, chyba lch nie czytywat w oryginale. Jedynym autorem, który zdaje się dobrze znać tragedię grecka z osobistej lektury, był Boecjusz; w jego bowiem pismach spotykamy wiele poprawnych cytatów, a jeszcze więcej reminiscencji, które suponuja tego rodzaju lekturą.

\section{Alıcja Stępniewska - Lublin}

\section{EST-CE QUE LES PERES LATINS DE L'EGLISE CONNAISSAIENT LES ECRIVAINS TRAGIQUES GRECS? /Résumé/}

$L^{\prime}$ auteur montre dans $I^{\prime}$ article la connaissance des écrivains tragiques grecs/les écrivains archaiques, Eschyle, Sophocle, Buripide, les ecrivains tardifs/ chez les Pères latins de l'Eglise. Cette connaissance - Eurlpide y prend la premiere place - est très supereicielle. Ello est due surtout aux études scolaires et à la lecture des autre auteurs latins. Il semble que seulement Boèce connaissait les tragédies grecques grâce à la lecture personnelle.

88 Por. De pallio 6, 1, CCL 2, 750; De pudicit1a 8, 11, CCL 2, 1296. 89 Por. Epistola $10 \% 38 \%, 8, \mathrm{CSEL} 82,76$.

90 Contra academicos III 4, 7, CCL 29, 38, tłum. K. Augustyniak /D1alogi Filozoficzne/ I 105: "/.../ wolarbym, abyśs pozwolit nam posłuchác swoich własnych wierszy, niż zebyś wyśplewywał z owych greckich tragedil słowa, których nie rozumiesz". 